\title{
Biology of the tea mosquito bug (Helopeltis theivora Waterhouse) on Chromolaena odorata (L.) R.M. King \& H. Rob.
}

\author{
K.K. Srikumar ${ }^{1 *}$, and P. Shivarama Bhat ${ }^{1}$
}

Helopeltis theivora Waterhouse, pest of tea, is emerging as a commonly occurring major pest of cashew (Anacardium occidentale L.) in recent times. The field observation revealed Chromolaena odorata (L.) R.M. King \& H. Rob. weed support as an alternate host of this pest during off season of cashew. Biology of $H$. theivora on this weed was studied for the first time. The incubation period of eggs was $10.5 \pm 1.2 \mathrm{~d}$. The $1^{\text {st }}, 2^{\text {nd }}, 3^{\text {rd }}, 4^{\text {th }}$ and $5^{\text {th }}$ nymphal instar developmental times were $36.11 \pm 9.52,43.29 \pm 7.35,27.15 \pm 8.41,41.31 \pm 10.13$, and $73.91 \pm 5.67 \mathrm{~h}$, respectively. Survival percentage of eggs was lower $(60.53 \%)$ than nymphal instars. Adult females and males lived for $22.6 \pm 3.29$ and $11.8 \pm 1.64 \mathrm{~d}$, respectively. Females showed dynamic patterns of fecundity with the number of eggs laid per female ranging 19 to 34 . Longevity and fecundity of $H$. theivora on this weed were significantly lesser when compared on cashew. Egg parasitoids viz., Telenomus sp., Chaetostricha sp. and Erythmelus helopeltidis Gahan were recorded from H. theivora eggs on C.odorata for the first time. For better management decisions, it is important to know about this mirid biology, particularly their life cycle on their alternate hosts so that the right assessment can be made before taking up spray.

Key words: Biological parameters, Chromolaena odorata, egg parasitoids cashew, Helopeltis theivora.

\section{INTRODUCTION}

Cashew (Anacardium occidentale L.) is one of the important export commodities of India. The increase in productivity of cashew is marginal during last decade in spite of introduction of high yielding varieties. One of the reasons for this condition is the lack of adoption of management strategies for controlling the common pest at cashew plantations i.e. Helopeltis spp. (Helopeltis antonii, Helopeltis bradyi, and Helopeltis theivora). Among these, H. theivora is a major pest of cocoa and tea in India and Asia. It also has been reported damaging other economically important plants such as black pepper, camphor, cashew and cinchona (Stonedahl, 1991). Additional host plants of this species were given by Miller (1941) and Das (1984).

Chromolaena odorata (L.) R.M. King \& H. Rob. (formerly: Eupatorium odoratum L.), herbaceous perennial belongs to the family Asteraceae (=Compositae), is recorded as the alternate host of $H$. theivora in the cashew plantations. It is primarily a noxious weed in cashew, rubber, and coconut plantations, grazing land and

${ }^{1}$ Directorate of Cashew Research, Puttur, Dakshina Kannada, Karnataka 574202, India.

*Corresponding author (sreeku08@gmail.com).

Received: 12 February 2013.

Accepted: 4 April 2013.

doi: $10.4067 /$ S0718-58392013000300015 disturbed forest areas (Subbaiah, 1992). It was reported that removal of the alternate host of $H$. theivora, thoroughwort (Eupatorium sp.), Fragrant thoroughwort (Eupatorium odoratum), from in and around tea plantations would give a good control of this pest in tea (Somnath et al., 2009).

Chromolaena odorata from its original point of introduction as an ornamental plant in northeastern India in the mid nineteenth century has spread throughout Southeast Asia, into parts of Oceania (Muniappan and Marutani, 1988; McFadyen, 1989; Waterhouse, 1994), and into West and Central Africa (Gautier, 1992; Prasad et al., 1996). It grows to a height of $3 \mathrm{~m}$ in the open situation and up to $8 \mathrm{~m}$ when assumed a scrambling habitat in the interior forests. It is native to Mexico, the West Indies, and tropical South America; it was spread widely by early navigators. It is widespread in the Western Ghats region covering Karnataka, Goa, Kerala, and Tamil Nadu states. This weed offer excellent hiding places and serve as alternate host of $H$. theivora.

Plants grow vigorously throughout the wet season and flowering is initiated by a decrease in both day length and rainfall (Sajise et al., 1974; Gautier, 1993). Chromolaena odorata grows extensively with vegetative growth and flowers throughout the year during June-December. The build-up of populations of $H$. theivora commences on $C$. odorata during August and reaches peak during September-November and thereafter declines. The population of $H$. theivora was completely absent from December to July on $C$. odorata while it was maximum 
on cashew during December-January coinciding with flushing and flowering on of cashew. The flowers of $C$. odorata are also visited by insects and $C$. odorata is an important honey plant in Thailand (Thapa and Wongsiri, 1997).

It is important to understand the biology of the pest in their alternate hosts to understand the mode and degree of its population growth. Although, the reports of occurrence and epidemics of $H$. theivora have been documented on various hosts (Stonedahl, 1991), details of the biological parameters were not explored. Since, life history and pattern of biological activities of an insect may vary in its different host plants, laboratory studies have become essential. Studies conducted in the laboratory using $C$. odorata shoots with tender leaves with detailed observations of reproductive and developmental stages of $H$. theivora formed the basis for the present study. Prevention methods are the most important key that should be applied regularly to protect cashew plants from the pest infestations. This study therefore, was sought to determine the biological parameters and natural enemies (egg parasitoids) of $H$.theivora on $C$.odorata, which may facilitate in recognizing the carry over potential of this pest in cashew ecosystem. That aid in formulating the Integrated Pest Management (IPM) for H. theivora on cashew.

\section{MATERIALS AND METHODS}

\section{Biology of $\boldsymbol{H}$. theivora on C. odorata}

Biology of $H$. theivora was studied under laboratory conditions at Directorate of Cashew Research, Puttur, Karnataka $\left(12.45^{\circ} \mathrm{N}, 75.4^{\circ} \mathrm{E}\right.$; $90 \mathrm{~m}$ a.s.1.), India. Adults of Helopeltis theivora were collected using long test tubes from cashew fields. Nylon mesh sleeve cages (170 $\mathrm{cm}$ long $\times 30 \mathrm{~cm}$ diameter) were used to confine these adult bugs after pairing adult bugs on tender flushing shoots of $C$. odorata in the field during July-December of 2011. Both ends of the cage were securely tied to prevent the insects from escaping. The shoots were kept in their natural position by tying the upper part of the sleeve cage to a stake and lower part to the twigs. The sleeve cages were labeled with oviposition date and precautions were taken to prevent the disturbance from ants.

The presence of a pair of fine respiratory filaments projecting from the surface of the plant tissue was indicative of the presence of eggs embedded in the shoot. Such shoots were brought to the laboratory from fifth to seventh day after oviposition. Immediately after hatching, nymphs were transferred individually in nymphal rearing cages (size: $15 \times 15 \times 20 \mathrm{~cm}$ and thickness: 18 gauge) developed by Sundararaju and John (1992). Four glass vials of $5 \mathrm{~mL}$ capacity fixed on a small aluminum stand with a handle of $15 \mathrm{~cm}$ height fixed at the centre were placed in each rearing cage. The fresh $C$. odorata shoots kept in water filled vial were supplied as feed on every alternate day. Observations were made on the changes that took place during incubation period and duration of nymphal instars. Further, the newly emerged males and females were paired and enclosed in the sleeve cages in fresh tender shoots of $C$. odorata in the field. Observations were made on varies biological parameters viz., incubation period of eggs, duration of nymphal instars, percentage survival, longevity of adults and fecundity.

\section{Study of egg parasitoids of $\boldsymbol{H}$. theivora on $\boldsymbol{C}$. odorata}

Surveys were made for $H$. theivora damaged $C$. odorata weeds in the cashew plantations. Eupatorium damaged stems containing eggs of $H$. theivora were collected from the cashew plantations. The exposed respiratory horns of egg cap are similar in appearance to the short downy white hairs on stems of $C$. odorata fairly making them virtually difficult to see. The eggs were counted under zoom microscope and treated in carbendazim (methyl benzimidazol-2-ylcarbamate, $0.1 \%$ ) solution for 10 min. After treatment, samples were dried to remove the dampness of carbendazim solution. Dried eggs were kept separately on large glass tubes wrapped with black cloth expect the top region. Eggs were collected and observed from July to December of 2012.

\section{Comparative biology of $\boldsymbol{H}$. theivora on $C$. odorata and A. occidentale}

The biological parameters of $H$. theivora on $C$. odorata were compared with that on cashew (Srikumar and Bhat, 2012). Data were analyzed using ANOVA F-test.

\section{RESULTS AND DISCUSSION}

During the period of studies, no incidence of $H$. theivora was seen on $C$. odorata from December onwards. This may be attributed to the non-availability of preferred stage of host plant and further the migration of the pest to its main host cashew. These results are in line with Sudhakar (1975), who noticed the peak incidence of the $H$. antonii during October on guava. The report of Onkarappa and Kumar (1997) revealed the incidence of the pest was seen from July to October. Das (1984) also reported that in the tea growing regions of north-east India, $H$. theivora reaches peak abundance in the period from June to September; with population levels gradually declining in November as cooler weather conditions prevail. The spread of pest symptoms from $C$. odorata to cashew was clearly observed during the present study (Figures 1 and 2).

Mean developmental periods of first, second, third, fourth and fifth instars were 36.11 $\pm 9.52,43.29 \pm 7.35$, $27.15 \pm 8.41$, and $41.31 \pm 10.13$, and $73.91 \pm 5.67 \mathrm{~h}$, respectively, i.e., the developmental period of third instar nymphs of $H$. theivora were shorter (1.0-2.0 d) compared to first instar (1.16-2.25 d), second instar (1.29-2.13 d), fourth instar (1.00-2.33 d) and fifth instar nymphs 


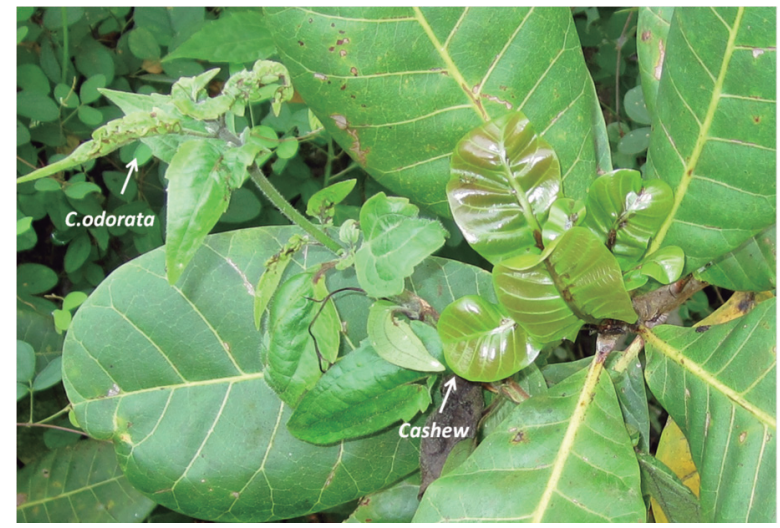

Figure 1. Damage spread from Chromolaena odorata to Anacardium occidentale.

(2.71-3.83 d) (Table 1). Helopeltis theivora reared on $C$. odorata under laboratory conditions had developmental periods of $233.26 \pm 21.39 \mathrm{~h}$ for males and $219.27 \pm 1.62 \mathrm{~h}$ for females. The total developmental period on $C$. odorata was not significant $(\mathrm{P}<0.05)$ when compared with that on cashew (Figure 3).

The total developmental period of a closely related species $H$. antonii reared under constant temperature of 19 to $35{ }^{\circ} \mathrm{C}$ on cashew flushing shoots was $231.37 \mathrm{~h}$ (Srikumar and Bhat, 2011). It was observed in the present work that the $5^{\text {th }}$ instar nymphal life span was highest for H. theivora. This is in accordance with Smith (1979), who recorded longest development period of fifth instar for $H$. clavifer.

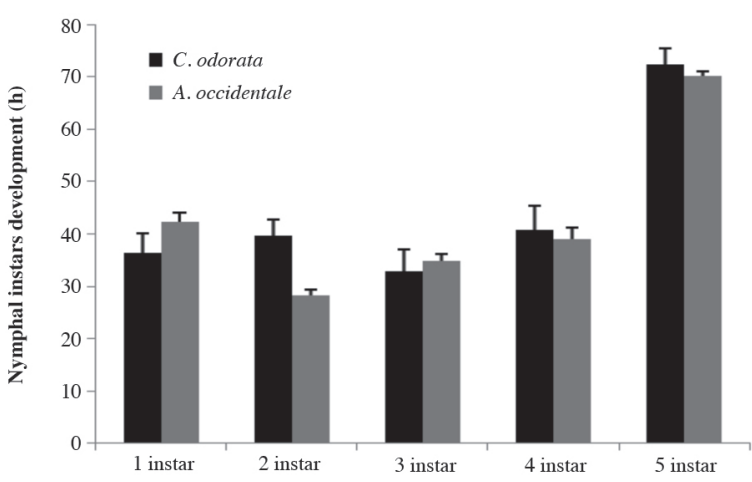

Data are mean \pm SE. Total developmental periods were non significant according to F-test $(\mathrm{P}<0.05)$.

Figure 3. Helopeltis theivora nymphal instars development on Chromolaena odorata and Anacardium occidentale.

While the survival of first, second and third instars were $93.33 \%, 92.87 \%$, and $97.43 \%$ respectively, the fourth and fifth instars had only $89.47 \%$ and $73.52 \%$ survival (Table 1). The survival rates were higher for first and second and third instar nymphal stages. The decline in survival rates for subsequent instars might, therefore, be attributed to additional nutritional requirement during the instar development. However, $73.52 \%$ survival in the fifth instar nymphal stage signified that $C$. odorata weed as an alternate host of $H$. theivora. Moreover, this result is quite comparable with the study of Somnath et al. (2009), who recorded $66.6-70.6 \%$ of survival of $H$. theivora nymphs on tea.

Table 1. Biological parameters recorded of Helopeltis theivora on Chromolaena odorata.

\begin{tabular}{|c|c|c|c|c|c|c|c|c|}
\hline \multirow[b]{2}{*}{ Particulars } & \multicolumn{5}{|c|}{ Developmental period of instars } & \multicolumn{2}{|c|}{ Total developmental period } & \multirow{2}{*}{$\begin{array}{l}\text { Incubation } \\
\text { period for eggs } \\
\text { (d) }\end{array}$} \\
\hline & First & Second & Third & Fourth & Fifth & Male & Female & \\
\hline Mean $\pm S D, h$ & $36.11 \pm 9.52$ & $43.29 \pm 7.35$ & $27.15 \pm 8.41$ & $41.31 \pm 10.13$ & $73.91 \pm 5.67$ & $233.26 \pm 21.39$ & $219.27 \pm 1.62$ & $10.5 \pm 1.29$ \\
\hline Range, d & $1.16-2.25$ & $1.29-2.13$ & $1.0-2.0$ & $1.00-2.33$ & $2.71-3.83$ & 8.29- 11 & 9.17-9.45 & $9.0-12$ \\
\hline Number of observations & 45 & 42 & 40 & 39 & 35 & 15 & 11 & 75 \\
\hline Survival, $\%$ & 93.33(9.66) & $92.87(9.64)$ & 97.43(9.87) & $89.47(9.46)$ & $73.52(8.57)$ & $79.12(8.89)$ & $81.43(9.02)$ & $60.53(7.73)$ \\
\hline
\end{tabular}

Values in parenthesis are square root transformed.

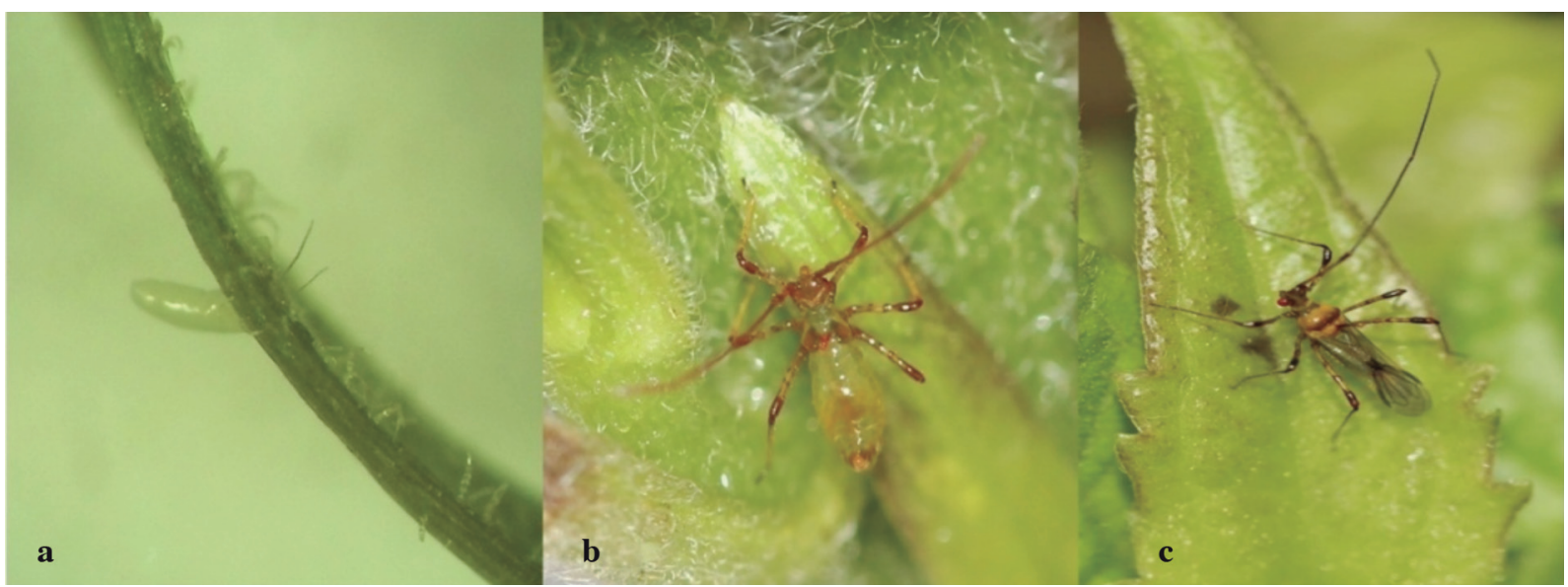

Figure 2. (a) Helopeltis theivora egg, (b) nymph and (c) adult on Chromolaena odorata. 
The mean incubation period of eggs was $10.5 \pm 1.29$ (9-12) d with $60.53 \%$ survivals. Mean longevity of adult females was $22.6 \pm 3.29 \mathrm{~d}$ with a range of 19-25 d.

The male longevity was significantly $(\mathrm{P}<0.05)$ lower on $C$. odorata than on cashew (Figure 4) and female longevity was not significantly different (Figure 5). The pre reproductive period varied from 4 to $6 \mathrm{~d}$ with a mean of $4.8 \pm 0.84 \mathrm{~d}$ (Table 2$)$. Fecundity was significantly $(\mathrm{P}<$ $0.05)$ lower $(30.6 \pm 6.50)$ on $C$. odorata when compared with cashew (Figure 6). Post reproductive period varied from 2 to $4 \mathrm{~d}$. Adult males lived lesser than females with a mean longevity of $11.8 \pm 1.64 \mathrm{~d}$.

A total of 107 eggs of eupatorium were observed and the results indicated the existence of three species of egg parasitoids viz., Telenomus sp. (laricis group) (Hymenoptera: Scelionidae), Chaetostricha sp. (Hymenoptera: Trichogrammatidae) and Erythmelus

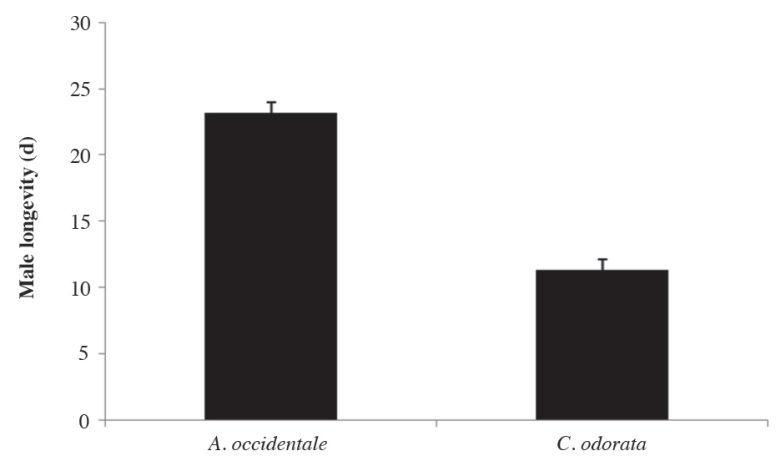

Data are mean $\pm \mathrm{SE}$.

Figure 4. Helopeltis theivora male longevity on Chromolaena odorata and Anacardium occidentale.

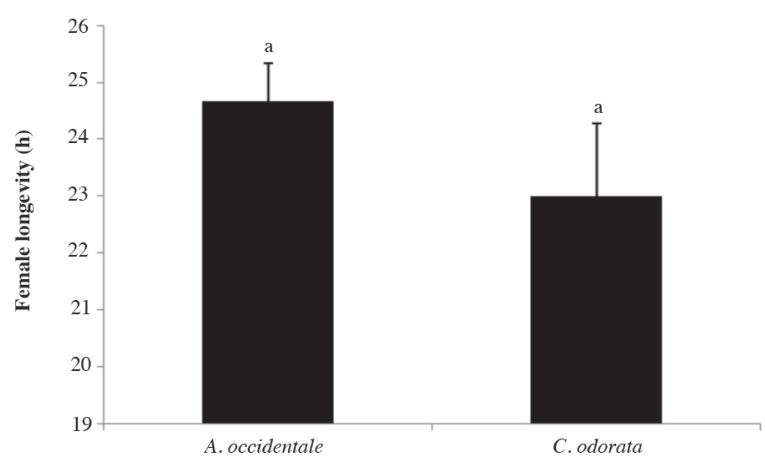

Data are mean \pm SE. Same letters are non significant according to F-test $(\mathrm{P}<0.05)$

Figure 5. Helopeltis theivora female longevity Chromolaena odorata and Anacardium occidentale.

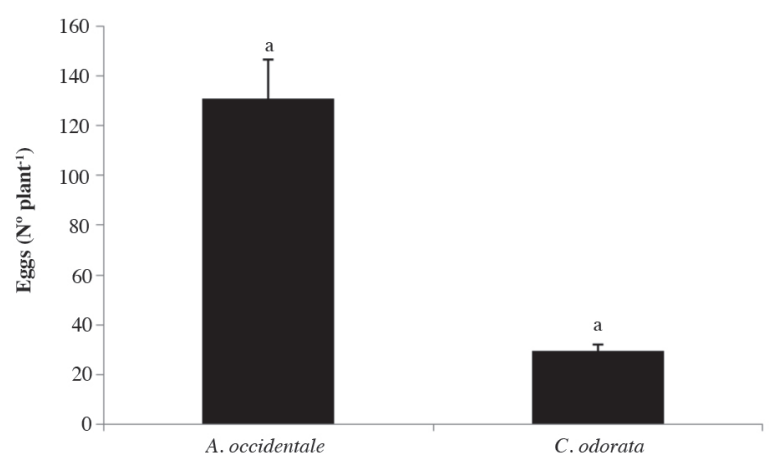

Data are mean \pm SE. Common alphabets are non significant according to F-test $(\mathrm{P}<0.05)$.

Figure 6. Helopeltis theivora fecundity on Chromolaena odorata and Anacardium occidentale.

helopeltidis Gahan (Hymenoptera: Mymaridae). Of these three species, Telenomus sp. was most frequently collected (Table 3 and Figure 7). For the first time, egg parasitoids were recorded from $H$. theivora eggs on C. odorata. Earlier Telenomus sp. has been reported in India on $H$. cinchonae Mann (Simmon, 1970), on $H$. theobromae Miller from Malaysia (Ibrahim, 1989) from cocoa, and both Telenomus sp. and Chaetostricha sp. on $H$. antonii Signoret from India (Sundararaju, 1993) from cashew. Erythmelus helopeltidis has been reported from $H$. antonii eggs by Devasahayam and Nair (1986) and

Table 3. Egg parasitoids recorded of Helopeltis theivora eggs on Chromolaena odorata.

\begin{tabular}{lccc}
\hline $\begin{array}{l}\text { Number of } \\
\text { Helopeltis } \text { eggs } \\
\text { observed }\end{array}$ & Percent parasitism (\%) \\
\cline { 2 - 4 } & Telenomus sp. & Chaetostricha sp. & $\begin{array}{l}\text { Erythmelus } \\
\text { helopeltidis }\end{array}$ \\
\hline 107 & 3.74 & 1.87 & 1.87 \\
\hline
\end{tabular}

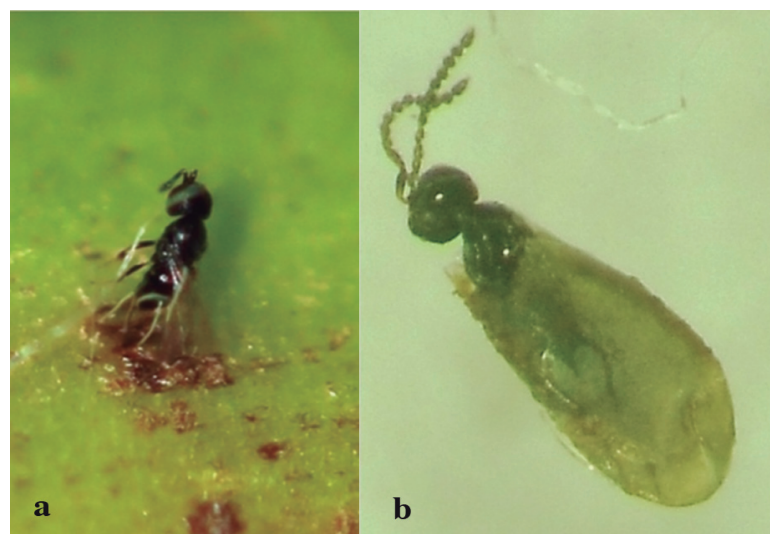

Figure 7. (a) Telenomus spp. parasitizing eggs (b) Telenomus spp. emerging from Helopeltis theivora egg.

Table 2. Reproductive parameters and longevity of Helopeltis theivora on Chromolaena odorata.

\begin{tabular}{|c|c|c|c|c|c|}
\hline \multirow[b]{2}{*}{ Particulars } & \multirow{2}{*}{$\begin{array}{l}\text { Pre reproductive } \\
\text { period }^{2}\end{array}$} & \multirow{2}{*}{$\begin{array}{l}\text { Fecundity during effective } \\
\text { reproduction }^{1}\end{array}$} & \multicolumn{2}{|c|}{ Longevity } & \multirow{2}{*}{$\begin{array}{l}\text { Post reproductive } \\
\text { period }^{2}\end{array}$} \\
\hline & & & Male $^{1}$ & Female $^{1}$ & \\
\hline Mean \pm SD & $4.8 \pm 0.84$ & $30.6 \pm 6.50$ & $11.8 \pm 1.64$ & $22.6 \pm 3.29$ & $2.8 \pm 0.84$ \\
\hline Range & 4-6 & 19-34 & 9-13 & 19-25 & $2-4$ \\
\hline
\end{tabular}

${ }^{1}$ Based on 20 individuals; ${ }^{2}$ based on 10 individuals. 
Sundararaju (1993). Erythmelus helopeltidis was also reported on H. theobromae Miller in cocoa from Malaysia (Ibrahim, 1989).

Adult egg parasitoids must not only find hosts for reproductive purposes but also locate food to meet their short-term nutritional needs. Both host and host habitat characteristics can be learned when a parasitoid has a contact experience with host, host products, or host plants (Lewis and Tumlinson, 1988; Herard et al., 1988; Turlings et al., 1989); a broader understanding of tritrophic level interactions that encompasses parasitoid food considerations can enhance our ability to design effective biological control strategies.

\section{CONCLUSION}

The primary objective of this study was to understand the biological parameters of economically important pest, Helopeltis theivora on Chromolaena odorata. This weed acted as alternate host for build of population during July to December and no incidence of $H$. theivora was seen on eupatorium from December onwards; attributed to the non-availability of preferred stage of host plant and further the migration of the pest to its main host cashew. Survival percentage of eggs was lower than nymphal instars and survival percentage of $5^{\text {th }}$ instar nymphs was lower compared to $1^{\text {st }}, 2^{\text {nd }}, 3^{\text {rd }}$ and $4^{\text {th }}$ instars. Males had shorter life span compared to females. Females showed dynamic patterns of fecundity. One silver line of the study was that $C$. odorata also acts as the reservoir for egg parasitoids of $H$. theivora. The knowledge of biology on $C$. odorata, might aid in taking appropriate decision in IPM of this mirid bug in main crop. Furthermore, the present study also highlights the essentiality of weed management in cashew plantations.

\section{ACKNOWLEDGEMENTS}

The authors greatly acknowledge the Indian Council of Agricultural Research Network Project on Management of Sucking Pests for providing all financial support to carry out the work. We are also thankful to the Director, Directorate of Cashew Research, Puttur, for providing necessary facilities.

\section{LITERATURE CITED}

Das, S.C. 1984. Resurgence of tea mosquito bug, Helopeltis theivora Waterh., a serious pest of tea. Two and a Bud 31:36-39.

Devasahayam, S., and C.P.R. Nair. 1986. The mosquito bug, Helopeltis antonii Sign. on cashew in India. Journal of Plantation Crops 14:1-10.

Gautier, L. 1992. Taxonomy and distribution of a tropical weed, Chromolaena odorata (L.) R. King and H. Robinson. Candollea 47:645-662.

Gautier, L. 1993. Reproduction of a pantropical weed: Chromolaena odorata (L.) R. King \& H. Robinson. Candollea 48:179-193.
Herard, F., M.A. Keller, W.J. Lewis, and, J.H. Tumlinson. 1988. Beneficial arthropod behavior mediated by airborne semiochemicals. IV. Influence of host diet on host-oriented flight chamber responses of Microplitis demolitor Wilkinson. Journal of Chemical Ecology 14:1597-1606.

Ibrahim, W.A. 1989. Erythmelus helopeltidis, an egg parasitoid of Helopeltis theobromae in cocoa. The Planter 65:211-215.

Lewis, W.J., and J.H. Tumlinson. 1988. Host detection by chemically mediated associative learning in a parasitic wasp. Nature 331:257259.

McFadyen, R.E.C. 1989. Siam weed: a new threat to Australia's north. Plant Protection 4:3-7.

Miller, N.C.E. 1941. Insects associated with cocoa (Theobroma cacao) in Malaya. Bulletin of Entomological Research 32:1-15.

Muniappan, R., and M. Marutani. 1988. Ecology and distribution of C. odorata in Asia and the Pacific. p. 21-24. In R. Muniappan (ed.) Proceedings of the First International Workshop on Biological Control of Chromolaena odorata, Mangilao, Guam. FebruaryMarch 1988. University of Guam, Agricultural Experiment Station, Mangilao, Guam.

Onkarappa, S., and C.T.A. Kumar. 1997. Biology of tea mosquito bug, Helopeltis antonii Sign. (Miridae: Hemiptera) on neem. Mysore Journal of Agricultural Science 31:36-40.

Prasad, U.K., R. Muniappan, P. Ferrar, J.P. Aeschliman, and H. de Foresta. 1996. Proceedings of the Third International Workshop on Biological Control and Management of Chromolaena odorata, Mangilao, Guam. 15-19 November 1993. Publication 202. University of Guam, Agricultural Experiment Station, Mangilao, Guam.

Sajise, P.E., R.R. Palis, N.V Norcio, and J.S. Lales. 1974. The biology of Chromolaena odorata (L. King and Robinson) 1. Flowering behaviour, pattern of growth and nitrate metabolism. Philippine Weed Science Bulletin 1:17-24.

Simmon, F.J. 1970. A memorandum on the possibilities of biological control of cocoa infesting mirids. 9 p. Commonwealth Institute of Biological Control Report (Mimeographed).

Smith, E.S.C. 1979. Descriptions of the immature and adult stages of the cocoa mirid Helopeltis clavifer (Heteroptera: Miridae). Pacific Insects 20:354-361.

Somnath, R., G. Gurusubramanian, and M. Ananda. 2009. Variation of resistance to endosulfan in tea mosquito bug, Helopeltis theivora Waterhouse (Heteroptera: Miridae) in the tea plantation of the Sub-Himalayan Dooars, northern west Bengal, India. Journal of Bacteriology Research 1:029-035.

Srikumar, K.K., and P.S. Bhat. 2011. Comparison of the developmental and survival rates, adult longevity and fecundity of Helopeltis antonii Signoret (Hemiptera: Miridae) on different phenological stages of cashew. Journal of Plantation Crops 39:347-350.

Srikumar, K.K., and P.S. Bhat. 2012. Field survey and comparative biology of tea mosquito bug (Helopeltis spp.) on cashew (Anacardium occidentale Linn.) Journal of Cell and Animal Biology 6:200-206.

Stonedahl, G.M. 1991. The Oriental species of Helopeltis (Heteroptera: Miridae): a review of economic literature and guide to identification. Bulletin of Entomological Research 81:465-490.

Subbaiah, K.M. 1992. In Proceedings of the First International Workshop on Biological Control of Chromolaena odorata, Mangilao, Guam. February-March 1988. University of Guam, Agricultural Experiment Station, Mangilao, Guam.

Sudhakar, M.A. 1975. Role of Helopeltis antonii Sign. on causing scab on guava fruits, its biology and control. Abstract of M.Sc. $(\mathrm{Ag})$ Thesis. Mysore Journal of Agricultural Sciences 9:205-206.

Sundararaju, D. 1993. Studies on the parasitoids of Tea Mosquito Bug, Helopeltis antonii Sign. (Heteroptera: Miridae) on cashew with special reference to Telenomous sp. (Hymenoptera: Scelionidae). Journal of Biological Control 7:6-8.

Sundararaju, D., and N.J. John. 1992. Mass rearing technique for Helopeltis antonii Sign. (Heteroptera: Miridae)-An important pest of cashew. Journal of Plantation Crops 20:46-53. 
Thapa, R., and S. Wongsiri. 1997. Eupatorium odoratum: a honey plant for beekeepers in Thailand. Bee World 78:175-178.

Turlings, T.C.J., J.H. Tumlinson, W.J. Lewis, and L.E.M. Vet. 1989. Beneficial arthropod behavior mediated by airborne semiochemicals. VIII. Learning of host-related odors induced by a brief contact experience with host by-products in Cotesia marginiventris (Cresson), a generalist larval parasitoid. Journal of Insect Behaviour 2:217-225.
Waterhouse, B.M. 1994. Discovery of Chromolaena odorata in Northern Queensland, Australia. Chromolaena odorata Newsletter 9:1-2. 